\title{
Rethinking Terraces and Dry-Stone Walls in the Alps for Sustainable Development: The Case of Mombarone/Alto Eporediese in Piedmont Region (Italy)
}

\author{
Maria Anna Bertolino $1, * \mathbb{D}$ and Federica Corrado ${ }^{2, *}$ \\ 1 Centre Régional d'études des Populations Alpines (CREPA), 1933 Sembrancher, Switzerland \\ 2 Interuniversity Department of Regional and Urban Studies and Planning (DIST), \\ Politechnic University of Turin, 10125 Turin, Italy \\ * Correspondence: maria-anna.bertolino@crepa.ch (M.A.B.); federica.corrado@polito.it (F.C.)
}

check for

updates

Citation: Bertolino, M.A.; Corrado, F Rethinking Terraces and Dry-Stone Walls in the Alps for Sustainable

Development: The Case of

Mombarone/Alto Eporediese in

Piedmont Region (Italy).

Sustainability 2021, 13, 12122.

https://doi.org/10.3390/su132112122

Academic Editors: Annamaria Giorgi, Luca Giupponi and Thomas A. Clark

Received: 14 August 2021

Accepted: 28 October 2021

Published: 3 November 2021

Publisher's Note: MDPI stays neutral with regard to jurisdictional claims in published maps and institutional affiliations.

Copyright: (c) 2021 by the authors. Licensee MDPI, Basel, Switzerland. This article is an open access article distributed under the terms and conditions of the Creative Commons Attribution (CC BY) license (https:// creativecommons.org/licenses/by/ $4.0 /)$.

\begin{abstract}
Nowadays, agricultural terraces and dry-stone walls have become protagonists of a territorial "rebirth" through a process of resemantization that recognizes them as a local resource. In relation to this focus, this article deals with a specific case study located in the Mombarone/Alto Eporediese area, in the northern part of the Piedmont Region (Italy), where terraced landscapes represent a unique environmental heritage, which has been partially abandoned. In this article, we illustrate the process carried out by local institutions in the Strategic Plan "Dalla Dora al Mombarone" and by the European Project Interreg Alcotra "Vi.A.- Route of Alpine Vineyards" which have involved many stakeholders of the local communities. In particular, starting from the results obtained by the engagement of social and territorial scientists in the projects mentioned above, we examined how terraces can support the reconstruction of a specific sense of place by the local community and the implementation of a sustainable development model through innovative solutions that go beyond the tradition in a frame of a green, soft and inclusive economy.
\end{abstract}

Keywords: terraces and dry-stone walls; local development; sense of place; strategic planning; Piedmont Region

\section{Introduction}

In the last decade, fragile areas have become the protagonists of new forms of territoriality despite their marginality [1,2]. The "rebirth" and the transformation that territories are experiencing derive, in general, from a reinterpretation of their resources by the local communities [3-6]. In many fragile areas, especially in mountains, terraces and dry-stone walls represent a modern key resource. The focus of the communication is to show how terraces and dry-stone walls may support this rebirth by illustrating the process carried out by the local institutions in the Strategic Plan "Dalla Dora al Mombarone" and by the community in the European project Interreg Alcotra "Vi.A.- Route of alpine vineyards". These two experiences have given attention to a complex idea of agriculture which involves cultural and economic aspects. First of all, agriculture is an activity which not only regulates the consumption of natural resources and controls hydrogeological risks, but also spreads an important sense of community. Secondly, it can bring a new approach in economic terms by fostering soft economy (Referring to the idea of soft power that exists in the political sciences, soft economy is a concept that aims to implement an alternative development model, combining social cohesion and competitiveness, in which the economy is based on know-how, innovation, local identity, history, creativity, and territorial quality [7]), green infrastructures and new forms of slow tourism (Slow tourism could be considered as a specific form of sustainable tourism in contrast to mass tourism. It refers to a behavioural mode while traveling. In this sense, it promotes the quality and the experience, a green approach through the consumption of local products, the preference of accommodation 
facilities with biosustainable architectures, and the use of transports with low $\mathrm{CO}_{2}$ consumption [8]) [9]. In the 3rd World Meeting on Terraced Landscapes ("Choosing the future", 2016) it was reiterated that "taking care of terraced landscapes means recognizing that they can respond in a concrete way to different [contemporary] requests: the preservation of the historical value $[\ldots]$, the explication of environmental and hydrogeological [ ... ] functions, the improvement of the quality of life through quality food products and forms of sustainable innovation, the sense of belonging" (http:/ /www.terracedlandscapes2016.it, accessed on 21 July 2021). Experimental replies are arriving from rural areas, at times calling experts from the outside, as bringers of new ideas who-through a cultural hybridization process with local knowledge - create new solutions and opportunities "which blends what it's internally (in local culture, landscape, environment, etc.) and what it is externally (financial and cultural ressources, new infrastructures, also virtual ones)" and in which "the past represents the roots for the future while modernity and tradition are used in an innovative way" [10]. We thus witness an experimentation of practices that considers two paradigms. The first concerns the idea that there can be innovation and experimentation in sparsely populated areas with a certain amount of social isolation. To quote the anthropologist Francesco Remotti and his theory about cultural impoverishment and cultural creativity [11], the idea that innovation only belongs to the urban context, where there is a greater concentration of networks and social opportunities, is challenged. On the contrary, innovation (and so cultural creativity) can also find the occasion to emerge in a context of social isolation and in the conservation of a natural environment from mass exploitation. From this point of view, the Alps seem to be a privileged observatory for the marginalization and absorption of urban models that occurred in the past-which could be read as impoverishment-and the ongoing renewal that, instead, involves creative and unexpected phenomena in a renewed and innovative relationship with the "centre" (i.e., the city). Today, cooperative work on agriculture, new entrepreneurship and renovated handcrafts are expression of this creativity. In addition, these aspects are finding social and cultural recognition not only in the changed relationship between the city and the mountains, but above all in the recognition of new physical and symbolic spaces in which they can be expressed [12]. The second paradigm concerns the fact that the local communities in such fragile mountain areas act as "problem solvers", as expressed in the 2004 Declaration of Lillehammer. They act as collective subjects with the ability to find new solutions to existing issues. In many mountain contexts around the world, it is crucial to keep terraces alive, not only as historic artefacts, but also as common goods on which to build a resilient local identity [13] and a part of territory that strongly contributes to local stability and production. Terraces are often places of "heroic" agricultural productions that contribute to the definition of specific identities. There are a large number of subjects acting locally-on different levels—on the terraces, to preserve and recover dry-stone walls, and they take on a key role in building local identity and a sense of belonging [14].

In this communication, our hypothesis has been that terraces can support the reconstruction of a specific sense of place by the local community and the implementation of a sustainable development model.

According to our focus, we have examined the following questions: what solutions (actions and policies) have been elaborated and supported in an innovative way, starting from the traditional elements, in a frame of green, soft and inclusive economy? What participatory approaches have been implemented in order to support these actions overcoming the top-down procedures?

The case-study presented regards the specific case of the Mombarone/Alto Eporediese area in the province of Turin (Piedmont, Italy), which has initiated the recognition of the value of terraces as a fundamental element to rebuild territorial identity and as a resource to implement new sustainable development paths.

In particular, the objective of this communication is to show the innovative processes carried out by local institutions and communities through instruments and tools of territorial planning (Strategic Plan "Dalla Dora al Mombarone" and the European project Interreg 
Alcotra "Vi.A.- Route of alpine vineyards"). The process carried out by local institutionsfollowed by this research group - and the ability of the local communities to innovate, have been incredibly effective. For this reason, The Mombarone/Alto Eporediese area is an interesting case study which could be transferred to other fragile areas distinguished by similar territorial resources.

\section{The International and National Recognition of the Values of the Terraced Landscapes}

In 1972, the United Nations Educational, Scientific and Cultural Organization issued the "Convention Concerning the Protection of the World Cultural and Natural Heritage", by which the knowledge and tangible/intangible elements of cultures worldwide were recognized - in order to safeguard their social, cultural, symbolic, and economic valuesas universal cultural heritage. This Convention has been reviewed over the years, and extended-first in 2003, then in 2005-through two more conventions: the "Convention for the Safeguarding of the Intangible Cultural Heritage", and the "Convention for the Protection and Promotion of the Diversity of Cultural Expressions".

In particular, the 2003 Convention included among the heritage to be protected even intangible elements, such as traditional knowledge on things, places, the environment, and nature. In fact, intangible cultural heritage includes practices, performances, expressions, knowledge, and know-how such as the use of tools, objects, artefacts, and the related cultural areas that the communities, groups, and individuals consider parts of their cultural heritage. The Convention states that intangible heritage is transmitted from generation to generation, and is constantly revived by communities and groups in response to their environment, their interaction with nature and their history. It provides them with a sense of identity and continuity, thus promoting respect for cultural diversity and human creativity.

Italy boasts eight elements of cultural heritage. The art of dry-stone walling, recognized in 2018, stands out among these (The second agricultural practice to be recognized by UNESCO, following a joint, transnational application by Cyprus, Croatia, France, Italy, Slovenia, Spain, and Switzerland). UNESCO has underlined that "the art of dry stone walling concerns the know-how related to making stone constructions by stacking stones upon each other, without using any other materials except sometimes dry soil [ ... ] drystone structures have shaped numerous, diverse landscapes, forming various modes of dwelling, farming and husbandry [ ... ] They play a vital role in preventing landslides, floods and avalanches, and in combating erosion and desertification of the land, enhancing biodiversity and creating adequate microclimatic conditions for agriculture" (https: / / ich.unesco.org/en/RL/art-of-dry-stone-walling-knowledge-and-techniques-01393, accessed on 21 July 2021).

Moreover, in 2006 the Alpine Convention issued a document titled "Declaration on Population and Culture", signed by all member states of the Alpine region, in which it is strongly highlighted that the safeguarding and development of Alpine territories requires a form of "strengthening community awareness and the identity of the people who live in it". Thus, the terraces fully enter the relationship between "doing" and the local community, which is the basis of local knowledge: "the care for and reconstruction of places to give value to elements of heritage in lasting and sustainable forms thus requires an active and conscious citizenship, able to combine context-specific knowledge with expert know-how through forms of participatory democracy" [15] (p. 4).

As for the national situation, it must be considered that about $16 \%$ of terraced surface area is indeed in the mountains, and a significant percentage of these is in the Alps. Here, terracing "represents a system of works resulting from traditional knowledge related to construction and farming techniques, and the perfect understanding of the hydrogeological and climate characteristics, enabling the subjects to make optimum use of the environmental resources" [16] (p. 49).

Terraced areas in Italy are often found in geomorphologically complex territories, and situations of geographic and socioeconomic marginalization, so expanded that the related farming activity is often described as 'heroic' [17]. Vine growing was the first among such 
activities to receive legislative attention (Article 7 of Italian Law n ${ }^{\circ} 238$ issued in 2012 and subsequently in 2016) with the aim to protect heroic or historic vineyards. A new standard also discusses criteria for the identification of territories. Heroic vineyards need to have at least one of: land inclination above 30\%; average height above 500 metres (1640 feet) a.s.l., with the exception of vineyards on a plateau; layout of the rows on terraces or steps; viticulture of the small plots.

These terraces are often included in the national register of rural landscapes of historic relevance and/or they relate to areas which have been recognized of outstanding universal value by UNESCO, stressing further the important value of these specific territories.

Even if the cultural, social and economic values of terraces are being recognised by international conventions and national registers, a lack of real investments and policies on their restoration and revalorizazion is still noticed at a national level. As Fontanari and Patassini write "the first problem to solve, at least in Italy (but the problem exists even in other countries), is the fragmentation of administrative powers between the three Ministries in dealing with TL [terraced landscape] from different perspective: cultural, environmental and productive. [ ... ] In observing the lessons from individual practices of re-appropriation of abandoned places or in catching the signals coming from the market dynamics, planning and policies for terraced landscape usually come very late (if they are not entirely missing)" [18] (p. 326). In fact, Marson notices that "this lack of institutional action is only partly counterbalanced by a number of pioneer initiatives. [ ... ] At the same time, these many bottom-up initiatives to keep terraced landscapes alive would be much more effective if institutional policies were sympathetic and collaborative in fostering the maintenance of terraced landscapes with new and coherent forms of multifunctional life" [19] (p. 337).

However, at regional and local levels, some evidence starts to emerge. After the recognition of the art of dry-stone walling by Unesco in 2018, the Regional Counsil of the Piedmont Region has signed an agenda item for the "Identification of appropriate economic resources for the maintenance, construction and renovation of dry stone walls" for the years 2019-2021. In particular, these financial ressources had to be found in the provisional budget, i.e reprogramming of the 2014-2020 Rural Development Programme (RDP) of the Piedmont Region. Terraces and dry-stone walls have already been cited in Measure 323 (Savegarde and riqualification of the rural heritage) of the previous Rural Development Programme (2007-2013). At a local level, some italian Local Action Groups (GAL) have developed their Local Development Plan 2014-2020, focusing on sustainable tourism. In them, local wine (produced in terraces) is mentioned as the main element of tourist attraction. The plans foresee the development of synergies that also involve minor typical productions in order to create integrated tourist products, partly diversified by target users. In this framework, in the Local Development Plan 2014-2020 of the Local Action Group (GAL) Valli del Canavese, entitled "Terre di economia inclusiva" (Lands of Inclusive Economy), terraces are cited in thematic area two "Valorisation of the diffuse architectural heritage and landscape", in measure 7.6.3 "Drafting and adaptation of manuals for the restoration of the rural architectural heritage and landscape" (Reg. 1305/2013 Art. 20par. 1 f) (http: / / galvallidelcanavese.it/wp-content/uploads/2020/12/11_Gal-Valli-delCanavese-PSL-Novembre-2020_def_pubblicazione.pdf, accessed on 29 October 2021). The steps undertaken by the Piedmont Region and by the Local Action Groups have been taken as a reference for the development of the research carried out on the specific case study, which will be defined in the next paragraph.

\section{Materials and Methods}

\subsection{Study Area}

The case study analysed concerns the area of Mombarone/Alto Eporediese, an area in the North Piedmont Region and bordering the Aosta Valley Region (see Figure 1). More specifically, the case study concerns an area including the alpine municipalities of 
Carema, Settimo Vittone, Nomaglio, Borgofranco d'Ivrea, Lessolo, Andrate, Chiaverano, and Montalto Dora.

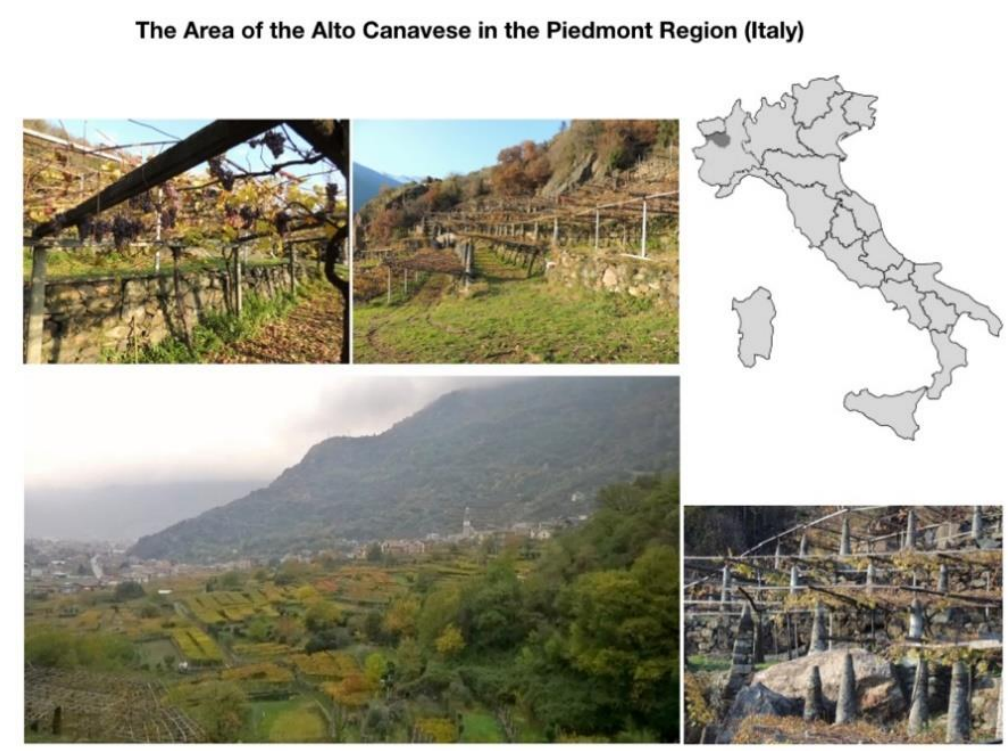

Figure 1. The Mombarone/Alto Eporediese area in the Piedmont region (Italy). Pictures and map by Maria Anna Bertolino.

The area is distinguished by a continuity of terraces, where the microclimate has favored the formation of a particular agricultural landscape featuring stone-walled terracing as well as an historical vine-growing. This setting also boasts the characteristic tupiun, pilun and balmetti: rural architectural elements of traditional agriculture activity able to produce - as a whole - a clearly identifiable and identity-making system. The use of terraces has changed over time, and as in other mountain areas, there has been a partial and gradual abandonment that led them to spontaneously grow wild. Nevertheless, over the past few decades, the desertion of the economic boom was followed by a conversion of former vineyards, especially replaced by other crops such as olive trees. What makes this territory similar to the others-despite the roughness of its slopes-is vine-growing on pergolas, whose intricate constructions became known as "topiary architecture". The technique is extremely complex and has a strong visual-perceptive impact with a clear value in terms of identity. Indeed, the historic and cultural value of terraces in the Alto Eporediese area finds a unique expression in the pergola vine-growing system nicknamed "valdostana" (see Figure 2), shared with nearby towns of the adjacent Aosta Valley Region, although the system is also popular elsewhere and for other crops [20].

This ingenious construction art once allowed farmers to use the little land available in the vertical sense: the vine grew on the topie and left the underlying land free to use for grass to make hay, for grazing purposes, or to farm crops. Given the sun exposure, the latter were appreciated delicacies sold at the main local markets.

Despite the fact that the latter use has vanished, the topiary architecture remains an essential feature of the region, and it has allowed the cultivation of Nebbiolo red grapes, which strive in an expanded crop setting when farmed in mountain areas. Certain small local businesses already see terraces as a dimension potentially giving a new economic, social, and environmental role to one of the territory's most precious resources. Such experiences have developed with different methods and practices given the local, specific situations. 


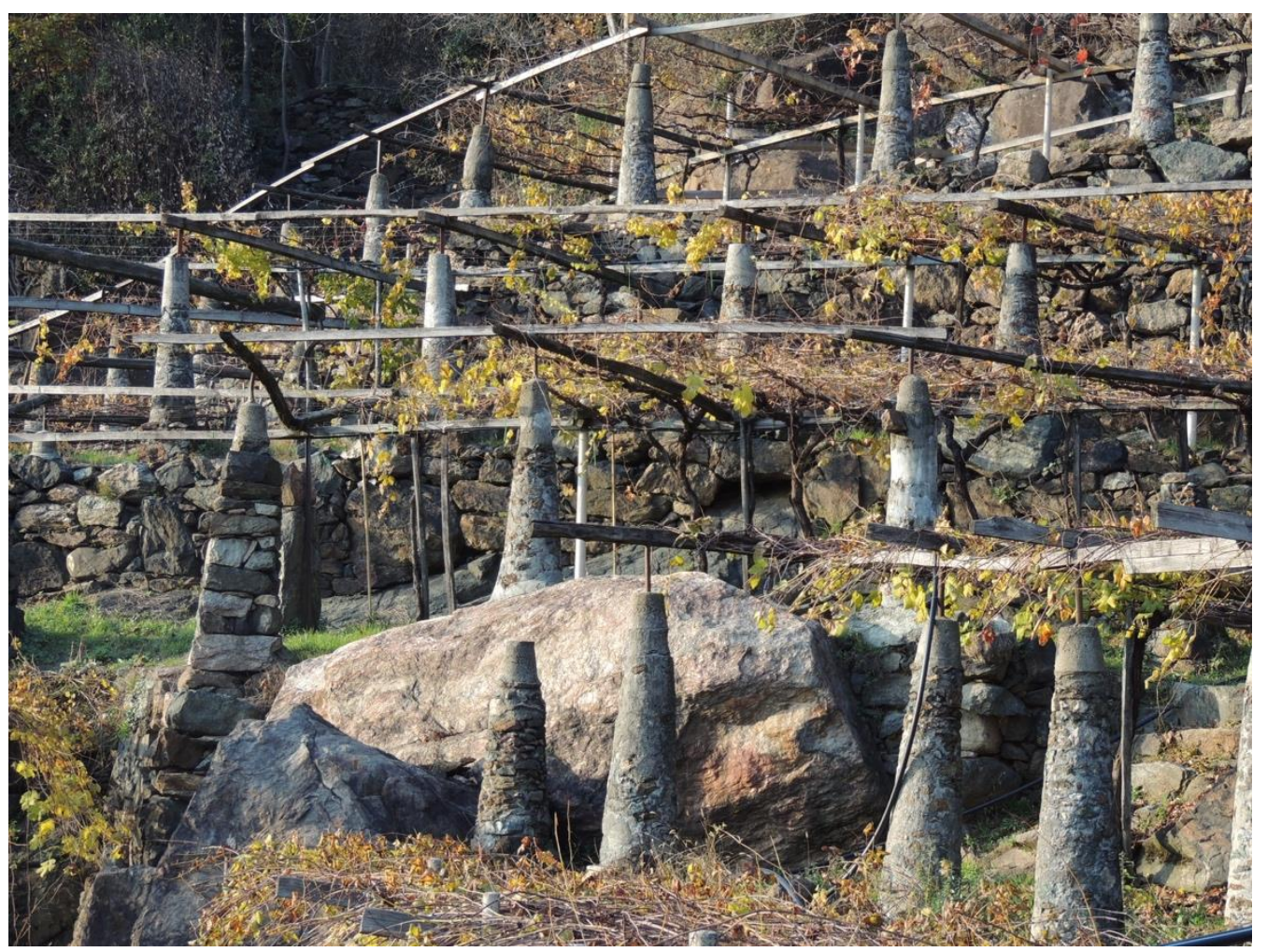

Figure 2. The traditional pergola (tupiun in the local dialect, or topia in Italian, which "topiary architecture" derives from) is composed of dry stone or stone and lime of a conical shape (pilun in the local dialect), with a flat and rounded capital at the top (a sort of cap), also made of stone, which hosts the beam connecting it to the dry-stone wall behind [21]. Picture by Maria Anna Bertolino.

In 2013, following urban design choices by Piedmont institutional bodies to position residual functions in these marginal areas, a group of mayors took the occasion to discuss the possibility to create an alternative future for local resources-and for terraces above all. It was also a chance to redefine the local identities-much too tarnished, in past years, by top-down decisions of the Piedmont Region-carried out through a collective process and shared by local community, with a promotion of local ability to shift from tradition into modernity [22].

\subsection{Methodological Approach}

The process of sustainable local development started about 8 years ago, and it involved different subjects at different levels, with the support of a scientific team leading during the entire process of analysis and territorial codesign (see Figure 3).

The first phase has been designed to create a strategic plan, presented to the local collectivity in autumn 2017 [23]. In terms of concept and method, the strategic plan has been developed on the basis of the definition and fine-tuning of strategic topic quadrants. This has allowed the grouping together of the different local resources identified in the explorative phase, in order to define the interaction between them. Defining the quadrants has allowed the prefiguration of planning perspectives in order to bring about collective, strategic and sustainable visions. The quadrants-with a broad definition and scope of topics - have been defined as follows: (a) landscape and environmental quality; (b) system of linear infrastructure; (c) historic, artistic, and architectural heritage; (d) leisure and outdoor activities; (e) tourist services and distinguishing features (see Table 1). 


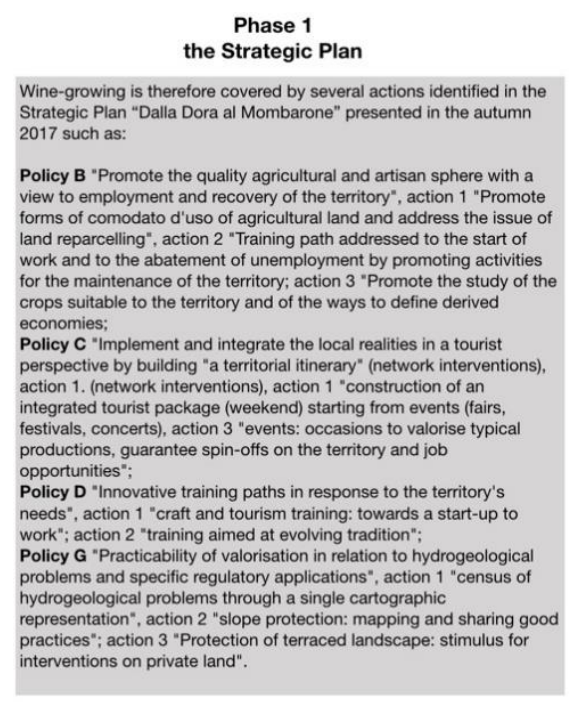

Phase 2

In this second phase, the process has been as follows:

- a recognition of local tangible and intangible "goods" related to the terraces and above all the vine-growing/winemaking activity and initiatives in such areas;

- specific questionnaire targeted to different business sectors; - moments of gathering and debate conducted in the form, of focus

The construction of specific institutional initiatives to promote and to encourage new entrepreneurships on terraces.

Figure 3. Diagram of the two phases of the research.

Table 1. The strategic topic quadrants of the Strategic Plan "Dalla Dora al Mombarone".

\section{Landscape and Environmental Quality}

1. A wide variety of quality environmental elements

2. Territories protected in relation to their fragile natural components

3. A difficult integration of environmental resources into touristic policies

\section{Historic, artistic and architectural heritage}

1. A vast stratification of historical assets with a strong integration into the landscape

2. A good offer of organized historical itineraries

3. A limited accessibility to specific historical assets

4. A limited synergy with other sectors, especially the economic one

\section{System of linear infrastructure}

1. A widespread, capillary road network

2. A good offer for so-called slow tourism (e.g., cycle-path and equestrian-path tourism)

3. Few investments into the railway despite its potential

\section{Leisure and outdoor activities}

1. A dynamic, cultural offer guaranteed by local associations

2. A good quality of social life guaranteed by many events

3. A very low level of integration between local thematic paths

4. A lot of possibilities to stay in contact with the environment through different sport activities

5. New farms which propose cultural events on traditional productions

\section{Tourist services and distinguising features}

1. A strong identity connotation linked to typical products

2. A natural landmark: the terraces

3. A family business in tourist sector (agritourism structure; production and sale of typical products

4. A very small touristic structure

5. Few touristic services (info point, tourism office) 
A specific investigation into the territory has been carried out through different tools:

- Semistructured interviews;

- World café method;

- Qualitative interviews to privileged stakeholders.

The application of this methodology in the first phase has been performed for each quadrant to include the local elements in a specific strategic context, assess the relationship between individual elements and their belonging to existing networks or circles, and identify their status of inclusion and relevance in the local policies and mechanisms. The relationships between resources have been investigated by also considering spatial interaction and morphological/physical conditions of the territory. Local resources have been included in more than one quadrant on numerous occasions. Such topic quadrants have thus allowed a delineation of the contents of the strategic plan and have contributed to the building and condensing of the profile of the area covered by the plan. Terracing emerged as a transversal element, finding space in more than one topic quadrant. More specifically, features recognized include its environmental and landscape value, its role as a part of the historic-artistic heritage, and its potential in terms of tourist services and local identity-making realities. A double role is recognized in terraces. The first role is linked to promotion of the high-quality agricultural and craftsmanship fields in the scope of employment and local recovery; it is implemented through actions to promote right of use of the agricultural land, research to find the most suitable crops for the area and training paths towards the start of work through maintenance of the territory. The second role is linked, through specific actions, to the feasibility of revaluing the territory given its hydrological and landscape issues, as well as the implementation of specific standards, with a special focus on private plots and the safeguarding of the landscape through shared urban actions based on reuse.

In 2018, one year after the presentation and adoption of the Strategic Plan by the municipalities involved, the inter-regional EU project called "Vi.a.- Strada dei vigneti alpini/Vi.a.- Route des vignobles alpins (Vi.a.- Trail of the Alpine Vineyards)" (founded by the inter-regional EU programme Alcotra and led by the Metropolitan City of Turin), has provided the opportunity to generate territorial policies. In particular the project-whose goal has been to promote and protect the Alpine vineyard landscape and winemaking activity in Italy and France- has provided the opportunity to focus on three small municipalities included in the strategic plan: Carema, Settimo Vittone, and Nomaglio. Here, the project has allowed the deepening of the potentialities of the territory in relation to the specific sector of terraces and vine-growing activities, in order to support experimental, sustainable and innovative practices to bring about the recovery of economic, cultural and social activities.

In the second phase, which lasted from August 2018 to April 2019, the process was as follows:

- A recognition of local, tangible and intangible "goods" related to the terraces and above all the vine-growing/winemaking activity and initiatives in such areas;

- A specific questionnaire targeted to different business sectors;

- Moments of gathering and debate conducted in the form of a focus group hosted by the municipality of Settimo Vittone. The focus group involved many local stakeholders such as mayors, cultural association, farmers, wine-makers, wine operators, touristic guides, museum guides, restaurants owners and caterers, owners of different local accomodations (hotels, b\&b, agritourisms, etc.), etc.

Following field audits, a questionnaire has been created, which considers the most common definition of wine tourism in research and documents, namely: "Visits for recreational purposes to vineyards, wineries, wine festivals and wine shows for which grape wine tasting and/or experiencing the attributes of a grape wine region are the prime motivating factors for visitors" [24]. 
The draft has been, instead, inspired by the Guida metodologica sul turismo del vino30 domande per gli Operatori Locali (methodology guide for wine tourism, 30 questions for local operators), a tool developed by CISET-International Centre of Studies on the Tourism Economy (Cà Foscari University of Venice) in cooperation with GAL Venezia Orientale (local action group for East Venice) (https://www.vegal.net/catalogo/web/ allegati/guida\%20metodologica.pdf, accessed on 25 July 2021). Topics investigated have been: perceptions related to winemaking (questions 1 to 3); the development of wine tourism (questions 4 and 5); promotion and communication initiatives for tourism purposes (question 6 and 7); and the potential offer designed for wine tourists (questions 8 and 9). Some questions have been rated on a Likert five-point scale, while other questions were multiple choice or open questions (see Table 2).

The questionnaire has been proposed to business subjects and to the volunteer associations working on the agriculture, on the touristic valorization and on the local cultural heritage in a paper version and in an online one.

A focus group has been organized in order to boost an open discussion between operators on the topic of the vine-growing/winemaking landscape related to the development of tourism, and to capitalize on the questionnaire results. Winemakers, restaurant and accommodation operators, shop owners, organizations, mountain guides, freelance workers, administrators, local action groups, and confederations of mountain towns in the different areas have been invited to join the focus group. The main research question has been: "What are the paths to take in wine tourism?".

Table 2. Table of the items of the questionnaire.

\begin{tabular}{|c|c|c|}
\hline \multicolumn{3}{|c|}{ Items } \\
\hline 1 & $\begin{array}{l}\text { If I say "local wine", what immediately do } \\
\text { you think about? (only } 1 \text { possible answer)? }\end{array}$ & $\begin{array}{ll}\text { - } & \text { A heroic agricultural practice } \\
\text { - } & \text { A local identity } \\
\text { - } & \text { A typical landscape }\end{array}$ \\
\hline 2 & $\begin{array}{c}\text { How much do you think has been invested } \\
\text { in and for the wine sector in your area in } \\
\text { the last } 10 \text { years? }\end{array}$ & $\begin{array}{ll}\text { - } & \text { Extremely } \\
\text { - } & \text { Very } \\
\text { - } & \text { Moderately } \\
\text { - } & \text { Slightly } \\
\text { - } & \text { Not at all } \\
\end{array}$ \\
\hline 3 & $\begin{array}{c}\text { Considering the characteristics of the } \\
\text { production area, which aspects do you } \\
\text { think are the most relevant for the } \\
\text { development of the wine sector ( } 3 \text { answers } \\
\text { maximum) }\end{array}$ & $\begin{array}{l}\text { - The physical and climatic } \\
\text { characteristics of the area } \\
\text { - Generational turnover of growers and } \\
\text { local producers } \\
\text { - Transmission of traditional know-how } \\
\text { in viticulture and winemaking } \\
\text { - The commitment of local institutions } \\
\text { - Territorial marketing to attract } \\
\text { - } \quad \text { The devists, buyers and consumers } \\
\text { purchasing activities in the area }\end{array}$ \\
\hline 4 & $\begin{array}{l}\text { How important do you think local wine is } \\
\text { for the area as a tourist attraction? }\end{array}$ & $\begin{array}{ll}- & \text { Not important } \\
\text { - } & \text { Slightly important } \\
\text { - } & \text { Fairly important } \\
\text { - } & \text { Important } \\
\text { - } & \text { Very important } \\
\end{array}$ \\
\hline
\end{tabular}


Table 2. Cont.

\begin{tabular}{|c|c|c|}
\hline & \multicolumn{2}{|c|}{ Items } \\
\hline 5 & $\begin{array}{l}\text { On a scale of } 1 \text { to } 5 \text { (where } 1=\text { not } \\
\text { important and } 5 \text { = very important), how } \\
\text { much can the development of "wine } \\
\text { tourism" help to: }\end{array}$ & $\begin{array}{l}\text { - } \quad \text { Defending the environment } \\
\text { - } \quad \text { Divereading a local rural culture } \\
\text { agricultural and local) } \\
\text { - } \quad \text { Qualifying and enhancing local } \\
\text { - } \quad \text { Sproduction by innovating it } \\
\text { - } \quad \text { Include craftsmen, restaurateurs, } \\
\text { - } \quad \text { Enriders, etc. in tourist circuits } \\
\text { products of neighbouring areas, } \\
\text { especially those characterised by mass } \\
\text { - } \quad \text { Increase employment and incomes } \\
\text { - } \quad \text { Empowering the local community to } \\
\text { work towards common goals }\end{array}$ \\
\hline 6 & $\begin{array}{l}\text { On a scale of } 1 \text { to } 5 \text { (where } 1=\text { not } \\
\text { important and } 5 \text { = very important), how } \\
\text { important do you consider such local } \\
\text { wine-based tourism development and } \\
\text { promotion initiatives to be? }\end{array}$ & $\begin{array}{ll}\text { - } & \text { Communication (brochures; } \\
\text { - } & \text { Odvertising campaigns; websites) } \\
\text { Organisation of events (festivals, fairs, } \\
\text { - } \quad \text { Creation of specific menus } \\
\text { - } \quad \text { Creation of circuits, roads, paths } \\
\text { - } \quad \text { Creation of / adherence to quality } \\
\text { labels/certifications } \\
\text { - } \quad \text { Creation of thematic tourist packages }\end{array}$ \\
\hline 7 & $\begin{array}{c}\text { Among the elements in point } 6 \text {, which do } \\
\text { you think have been implemented and } \\
\text { which should be improved? }\end{array}$ & Free answer \\
\hline
\end{tabular}

In your opinion, on a scale of 1 to 5 (where $1=$ not important and $5=$ very important),

8 how important are the following elements for wine tourists when they visit a wine production area? Shisitors" Hall, C.M N., E., Cambourne, B. \& Macionis, N., eds., 2000, translated from the XIIth report on tourism in Italy-City of Wine). In your opinion, on a scale of 1 to 5 (where $1=$ not suitable and $5=$ very suitable), how suitable is the area as a destination for wine tourists?

One of the definitions of wine tourism is:

"Visits for recreational purposes to vineyards, wineries, wine festivals and wine shows for which grape wine tasting and/or experiencing the attributes of a grape wine region are the prime
- $\quad$ Enjoying a typical cuisine

- Researching niche wines

- Take a tour of the cellar guided by an oenologist or the winegrower

- Going on vineyard tours

- $\quad$ Finding a welcoming area whose inhabitants can tell the local story

- Visiting local museums and historical, artistic and architectural heritage

- $\quad$ Enjoying outdoor activities

- Not suitable

- Slightly suitable

- Fairly suitable

- Suitable

- Very suitable 
The focus group has been inspired by the Appreciative Inquiry technique. This is a special type of research method used in the development of participatory pathways with a different setup than traditional methods, in that it is strongly oriented towards generating change. This implies the systematic discovery of that which inspires community life in a specific area, making the community stronger and more aware. Appreciative Inquiry is usually recommended when the aim is to create the best conditions possible to activate a collective change, focusing on the cognitive and emotional conditions favouring such change. This choice pushes individuals to restate and recontextualize negative issues to turn them into positive topics for the investigation [25].

The focus group exists between the explorative and the interpretative typology, with a medium level of structuration [26]. However, the participants have been involved in four phases, following the implementation of the Appreciative Inquiry technique:

○ Phase 1: participants have been committed to indicating the positive aspects related to wine tourism that exist in the area. The participants have been asked to reveal what is useful and positive in the area in order to understand what has been achieved so far. In this way, the strengths linked to the theme are identified, trying to enhance what has been done positively and reflecting on what already works;

○ Phase 2: Participants have been asked to think about what could be done in their area, and to indicate what they would like to achieve (or see achieved) in relation to wine tourism, in order to identify development opportunities linked to the area which are consistent with their expectations.

○ Phase 3: the participants have been asked to indicate possible ways of realising what was identified in phase 2 , reflecting on their own individual contribution and also highlighting any needs and criticalities of the area, and the elements which are currently hindering or in need of innovation or modification;

$\bigcirc \quad$ Phase 4: this is the phase in which the local administrations are confronted with the participants and then with the research team.

The focus groups have been recorded in order to transcribe the conversations, and the moderator was accompanied by a second researcher who was present to take notes on the nonverbal language.

Both the results of the questionnaire and the results of the focus group have been retrieved as a perceptual map and a SWOT analysis (see Table 3 and Figure 4).

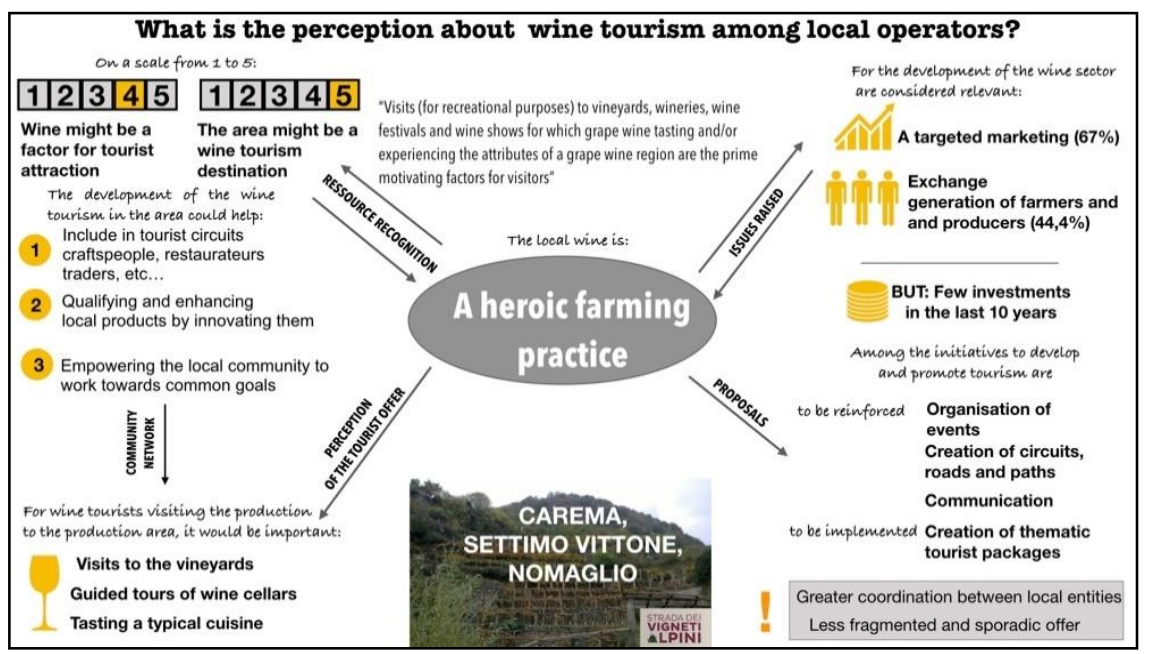

Figure 4. Perceptual map of wine tourism in the area included in the "Vi.A.- Route of alpine vineyard"s project. 
Table 3. SWOT analysis referring to the terraced landscape of the Mombarone/Alto Eporediese area.

\begin{tabular}{|c|c|}
\hline Strengths & Weaknesses \\
\hline $\begin{array}{l}\text { - Acknowledgement by the community of } \\
\text { topiary architecture as a unique feature in } \\
\text { the Piedmont landscape and of the heroic } \\
\text { nature of the farming practices; } \\
\text { Closeness of the } \\
\text { vine-growing/winemaking landscape to } \\
\text { other rising tourist attractions (Via } \\
\text { Francigena, for example); } \\
\text { Acknowledgement of the historic role as } \\
\text { passageway; } \\
\text { Presence of the Slow Food-certified } \\
\text { Carema wine; } \\
\text { Use of Carema wine in dishes prepared at } \\
\text { events; } \\
\text { Birth of new nonhotel accommodation } \\
\text { facilities; } \\
\text { - Cellars open to tourists at given times of } \\
\text { the year; } \\
\text { Presence of a trail among the vineyards }\end{array}$ & $\begin{array}{l}\text { - } \quad \text { Poor generational renewal; } \\
\text { - } \quad \text { Viticulture is often done in spare time; } \\
\text { Strong presence of abandoned terraces } \\
\text { despite the fact that many have already } \\
\text { benefited from public policies and } \\
\text { conversion (e.g., planting of olive trees); } \\
\text { - Abandonment of the pergola system } \\
\text { (expensive) by vine-growers and lack of } \\
\text { political action for its maintenance; } \\
\text { - Area of (very frequent) passage; } \\
\text { - Presence of businesses and } \\
\text { accommodation facilities concentrated in } \\
\text { the valley floor; } \\
\text { Wine exported abroad; } \\
\text { - Wine promotion initiatives concentrated } \\
\text { in certain moments of the year } \\
\text { (September); lack of events in the } \\
\text { remaining periods. }\end{array}$ \\
\hline Opportunities & Threats \\
\hline 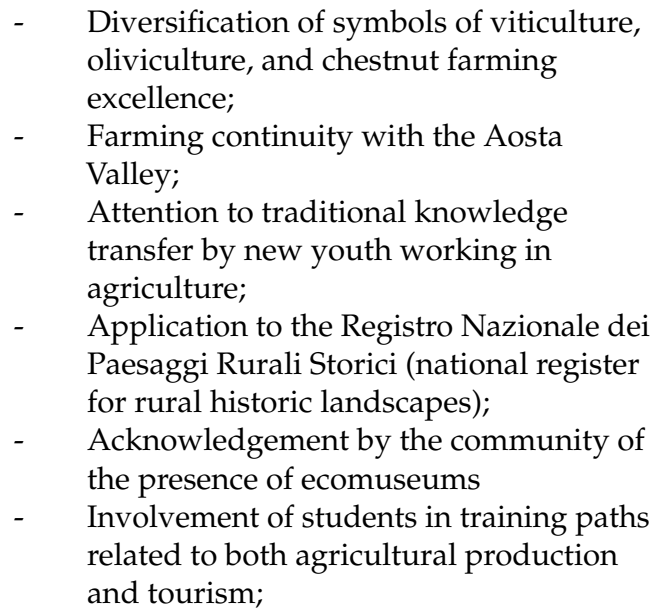 & $\begin{array}{ll}\text { - } & \text { Terracing in certain areas in clear state of } \\
\text { abandonment; } \\
\text { - } & \text { Old age of winemakers; } \\
\text { - } & \text { Industrial areas neglected or abandoned; } \\
\text { - } & \text { High maintenance cost of topiary } \\
\text { architecture; } & \\
\text { - } & \text { Current wine production is lower than its } \\
\text { demand (from abroad). }\end{array}$ \\
\hline
\end{tabular}

\section{Results}

The results of the research activities, carried out in the two phases illustrated, have highlighted elements that could be reinterpreted in the local development path. These elements have been synthesised in the following SWOT analysis.

Research-action work in the field has strongly highlighted the recognition of terraces as the fruit of local intellect and culture, and as a part of the mountain landscape, as well as goods to safeguard as they are strongly necessary for land management purposes. In the mountains, viticulture is among cultivations that have been assigned a high community value and have undergone continuous innovation [27,28]. For this purpose, the towns of Carema, Settimo Vittone, Nomaglio, and Borgofranco di Ivrea, along with the Osservatorio del Paesaggio per l'Anfiteatro Morenico di Ivrea (AMI-observatory for the morainic amphitheatre landscape of Ivrea) and the Associazione Italiana di Architettura del Paesaggio (Italian organization for landscape architecture), have launched the proposal to include the area in the national register for rural historic landscapes, farming practices, and traditional knowledge. The preapplication form states that the landscape in concern "has maintained a good level of integrity, as well as a sufficient extension allowing traditional farming to 
continue to be the main source of income from agriculture and strongly distinguishing the local landscape" [29].

In particular, the municipalities of the Alto Eporediese bear witness to a different value of wine-growing and wine-making in our times, which is reflected in the commercial and cultural activities undertaken. Carema, which has its own DOC (denomination of controlled origin), is the town with the greatest wine production. This production revolves around the Cantina Sociale (social cellar), which collects wine from different producers. As a distinguishing element of the Carema area, the identification of terraced landscape and local wine is quite strong. From a tourism perspective, we may notice that a new promotion was launched starting in the 2000s, with the creation of the trail among the vineyards and the recovery of about 100 pilun elements. The relaunch of the tangible aspect-the landscape-was followed by that of an intangible aspect-the Festa dell'Uva e del Vino (festival of grapes and wine, on its 68th edition in 2020). The celebration boasts strong popularity and-over the years—has aided the development of several intercity networks, offering a shopwindow for numerous wines from the entire Piedmont Region.

The attention towards the terraced landscape is also high in the towns of Settimo Vittone and Nomaglio. In the former, the abandonment of vine-growing and winemaking was followed by a recent conversion (in particular, to olive groves) of the plots. The attention towards wine from the Eporediese area-with its own DOC extending to various towns in the area-is particularly high. The wine is produced by individual winemakers, even those recently settled in the area. This level of attention is also proven by the inclusion of certain operations in wider-scale projects, such as "Attorno al Mombarone: Sentieri della fede and del cibo buono tra Valle Elvo and Canavese, lungo la Linea Insubrica" (around Mombarone: spiritual and good-food trails between the Elvo Valley and the Canavese, along the Insubria strip), which has allowed the opening of "La bottega del Viandante" (the wayfarer's shop) at a local inn: a "territory-specific shop" offering a shopwindow for local excellence (wine, olive oil, and chestnuts).

In general, the territory analysed in the case study shows a strong interest and activism in working to create communities and creating occasions and initiatives to strengthen local networks or develop extra-local networks [30]. This combines with the interest to define a method to recognize the territory and its products, as well as sharing local products among businesses. Local operators perceive it as an area with a strong wine-tourism potential. Both the area's value as a tourist destination and the terracing/wine resourcedescribed as a "heroic" practice-are fully recognized. Among the aspects considered most relevant to the development of the vine-growing and winemaking sector in each area of production, there is - on the one hand - the demand related to the commercial aspect, for which a specific territorial marketing strategy to attract tourists and local shops is considered a priority; on the other hand, there is the demand more closely linked to the area of know-how transmission between winemakers and generational renewal.

The most significant among local development and wine-tourism promotion initiatives are: the organization of events (festivals, food \& wine-based celebrations, conferences); the creation of circuits, roads, and trails; and communication (brochures, advertisement campaigns, websites). Likewise, other elements to boast are cultural, sports/leisure, and food \& wine events, which some operators say are too concentrated within the grape harvest period. The latter also report the need to ameliorate excursion circuits and nature trails, combining this with more modern marketing. Finally, the creation of theme-based travel packages related to wine shall be created, with improved collaboration between winemakers and restaurant/accommodation facility owners. The demands of wine tourists visiting the area of production are perceived to revolve strictly around the culinary experience: from cellar tours led by oenologists to tastings of traditional cuisine.

As for the promotion of tourism in the vineyard area between Carema, Settimo Vittone, and Nomaglio, one of the greatest hurdles is the maintenance of the territory. In particular, operators report poor accessibility and the absence of signs along the vineyard trails. This issue is related to that of generational renewal and the high costs of vine- 
growing and winemaking activity, which often do not guarantee an income, especially for the youth newly approaching the activity. To overcome such an issue, a trademark for heroic vine-growing in the mountain areas would allow one to stand out in the business and receive recognition for the hard (even financially speaking) work that this implies. Consumers are indeed-more often than not-unaware of how wine is processed in the mountains, and this creates a gap between the potential and effective demand (lower, as a consequence of the price). Being able to communicate agricultural skills is thus fundamental for businesses in such areas to stay alive, be competitive on the market, and stand out from other winemakers.

Among the results of the path taken by the local community, there was the creation of a workshop in the context of the Third World Meeting on Terraced Landscapes. This was also the chance to look beyond the local community and to extend the attention beyond regional borders to the Aosta valley (Italy). The Aosta valley is characterized by significant terraces both in the low part of the region inside the municipality of Donnas, Pont Saint Martin and Perroz, small agricultural towns, and in the high part of the valley in the area of Mont Blanc, mainly known for touristic reasons. Despite Piedmont Region and Aosta Region sharing territorial borders, the initiatives taken by different administrative bodies have shown different ways of acting on the terraces: in the Aosta Valley, management of local policies and projects was recorded to be more organized and mature, and in Piedmont, the administrators brought to the table their strategic work for the sharing of local heritage and the "re-vision" of promotion actions.

The event of the Third World Meeting has in any case been a strong stimulus for the local community. It has provided a deeper awareness of the presence of the terraces, and at the same time, it has given more relevance to the activities performed by local subjects concerning the terraced landscapes. The involvement of local subjects has become fundamental for the success of the initiative and has become an occasion to strengthen the local network of individuals acting in and operating on terraced landscapes. The Meeting has been not only an exchange of knowledge inside Italian subjects but also through people that come from different states and contexts, such as terraced landscapes of La Gomera in the Canary Islands, and terraced landscapes of Mediterranean areas such as France and Spain. The principal issues shared during the meeting are regarded as:

- Terraced landscape architecture and the related techniques;

- Management and promotion of local museums and ecomuseums;

- Places of raw material transformation - more specifically, winemakers;

- Intergenerational transfer of local know-how;

- Construction of supply chains and valorization of "heroic" products;

- $\quad$ Outdoor activities related to terraces.

Referring to this framework, institutional territorial actions have been reoriented in order to invest more in the valorisation of the entire production chain of the terraces. Summed up, local administrations have implemented and supported the following actions or policies:

The official recognition of terraces as part of a local heritage proposed to national and international bodies (such as the proposal to the "National Register for Rural Historic Landscapes, Farming Practices, and Traditional Knowledge" or the participation at the Third World Meeting on Terraced Landscapes);

- A new touristic promotion thanks to the creation of trails in the vineyards and the recovery of the pilun elements, and with several events that valorize tangible and intangible aspects by private-public partnerships;

- The conversion of abandoned plots (in particular, to olive groves) and the launch of new local products.

○ New entrepreneurial projects such as the opening of "La bottega del Viandante" in order to offer a shopwindow for local excellence (wine, olive oil, and chestnuts) on private initiative; 
The creation of theme-based travel packages related to wine, with improved collaboration between winemakers and restaurant/accommodation facility owners and institutional subjects.

\section{Discussion}

More generally, postindustrial society assigns the role of "collective heritage" to rural landscapes, as international conventions and political agreements state. In this context, the fact that rural land-when adequately farmed-produces not only subsistence goods, but even cultural and landscape heritage, has been ascertained. The case study underlines that mountain territory with its resources is not only a real and visible expression of tangible culture, it is also an exceptional launchpad for an integrated and sustainable territorial codesign and development; a catalyst allowing local communities to work together and at different level towards common goals.

Similar fragile areas characterized by terraced slopes have developed processes of enhancement of their territorial capital, focusing their action on the revitalization of the tangible and intangible aspects of terraces in a contemporary way. This is the case of the Canale di Brenta in Veneto Region (Italy). Through different activities, administrations at different levels (municipalities, provinces and regions) have managed a bottom-up process to involve the local community in a new development path [31,32]. In particular, four actions have been carried out:

$\bigcirc \quad$ The Interreg ALPTER project designed to counter the abandonment of terraced agricultural areas in the Canale di Brenta. This issue is considered a cause of the loss of cultural heritage and the increased natural risk of the area. The project has been designed to define some procedures in order to respond to some significant issues (geological hazard assessment and mapping; enhancement of slow tourism and of new forms of agriculture). On this basis, the project has explored new developmental scenarios of terraced areas and long-term recovery actions, involving governmental institutions and inhabitants in the reuse of terraced areas;

- The establishment of the Local Landscape Observatory of the Canale de Brenta, an experimental initiative to elaborate different forms of local landscape knowledge;

$\bigcirc$ The implementation of a training period on dry-stone wall construction under the LEADER programme;

- The foundation of an association based on volunteers work for the recovery of terraced areas through limited cultivation for personal use. This association has developed a specific project called "Adopt a terrace!", in which the association supports the management and the cultivation of terraces abandoned by local inhabitants.

As in the case analysed in this article, the process carried out on abandoned terraces is based on the recognition of local resources, and the involvement of the local community. Transcalarity is in both cases a necessary way to build the process and to include different territorial levels.

Contemporary society has assigned roles to rural/mountain spaces that transcend the satisfaction of primary needs: from the conservation of animal and plant biodiversity to the rediscovery of traditional farming techniques, landscapes such as terraced landscapes have become a cultural, natural, and often, tourism resource. In this scope, different interests and images, possibly divergent, come into play and call for an approach based on community empowerment [33-35]. Accordingly, certain items emerging from the analysis are outlined below. They are not only valid at a local level but also at a wider one. In particular, we would address similar territorial contexts where efficient and effective policies for a sustainable local development are required:

1. Recognition of the value of the local resources as a factor of tourist attraction, and the need to safeguard it with a bottom-up community approach

In particular, this concerns terracing, dry-stone walls, and stone architectures, while agricultural production is acknowledged - in general—as a magnet for new forms of 
tourism. This item highlights a number of criticalities. It underlines how it is necessary to create a suitably protected and maintained territory, even by including the topic of vine-growing and winemaking landscape in town plans.

2. Need to harmonize different forms of local tourism

A strong heterogeneousness of potential alternative tourism forms has emerged in this regard. In the light of such framework, wine tourism would run in parallel to other forms, with the awareness that in mountain areas it might not have the firepower to emerge independently. Ecotourism could nevertheless have the potential to relaunch existing forms of tourism, "rejuvenating" them, and satisfying new demands-slow tourism outdoors above all (trekking, bicycle tourism, etc.) — and rural destinations (wine and food culture, quality of life and of the air, etc.).

\section{Local culture-tangible and intangible-must be assigned new meanings}

The topic of rediscovering and relaunching history and local traditions is paired with an image of such traditions, not as fossilized elements, but as possible resources to promote the scope of a new, modern revamping of celebrations, local know-how, and historic origins.

4. Creation of "spaces" and networks with a vine-growing and winemaking vocation

The debate has brought about the idea of assigning a physical, distinguishing location to such vocation. The identification of one or more places must occur downstream of a collective research and discussion process. Moreover, cantine Sociali (social cellars) - where existing — may be assigned the role of local "shopwindows", but—more specifically — every single business can potentially be included in the vine-growing and winemaking promotion process. Whilst in some cases a close link between production and marketing of products in local shops already exists, in others it is entirely in the making.

5. Recognition of the need for training and the educational nature of terraces

It is proven that the vine-growing and winemaking sector requires qualified manual labour that is hard to find, also because of the lack of knowledge of the specific vine growing and dry-stone wall techniques. Nevertheless, a few examples in this direction concern the activation of professional training paths for the young and unemployed, in the scope of employment in local production. This is promising for the purposes of territorial quality maintenance. We also underline the need to organize training courses or events concerning the sensory qualities and history of local wines for operators willing to marketor which already market—such products (restaurant owners, shop owners, accommodation facilities, etc.).

\section{Conclusions}

Terraces are playing a leading role in the actual renaissance of rural territories that is being shaped, above all, by current practices and innovative policies [36,37]. Once the local community has recognized and has valued this natural component as a resource, terraces can support and foster process of regeneration. Local initiatives and actions highlight the visible and invisible relationships that are bound together and characterise the terraced landscape. Innovative policies, carried out on a place-based approach, help to overcome the crisis that has affected these territories and their traditional development models.

Specifically, the local know-how and the historical heritage represent "levers" for the implementation of new development strategies and new ideas for using territories in sustainable forms. In this sense, the collective, dialogic and inclusive process contributes to producing a territorial identity and a community-based conservation and valorisation, and to define a more sustainable development model in comparison to the traditional ones [38,39]. In this framework, the valorisation of the resources of the terraces implies the care of the territory, the strengthening of the historical tradition, the practice of a new agriculture to achieve a new paradigm of development aimed at reducing the consumption 
of natural resources, controlling of environmental risks, promoting greater energy efficiency, a drastic reduction in local pollution, social inclusion and liveability.

More generally and in relation to this framework, three issues should be implemented in rural or mountainous territories:

- New forms of agriculture that attempt to experiment with innovative forms of the primary sector, also supported by return migrations to the mountains (so new mountaindwellers)

New forms of tourism that enrich the exchanges between visitors and inhabitants, and that promote local history and identity through the involvement of the tourists in agricultural activities on terraces (such as during the grape harvest)

- New cultural activities that combine tradition and innovation: terraces are involved in some new forms of cultural and artistic production (e.g., wine and food events, sets for land art). A kind of slow landscape, in contrast to urban life, which is inspiring artistic innovations.

Author Contributions: Conceptualization, M.A.B. and F.C.; methodology, M.A.B. and F.C.; validation, M.A.B. and F.C.; writing-original draft preparation, M.A.B. and F.C.; writing-review and editing, M.A.B. and F.C. All authors have read and agreed to the published version of the manuscript.

Funding: The research carried on in the European Project Interreg Alcotra "Vi.A.- Route of Alpine Vineyards" (WP 3.2-4.2 Awareness raising, training and involvement of actors and ambassadors) was financed by Città metropolitana di Torino.

Institutional Review Board Statement: Ethical review and approval were waived for this study, due to reason, that this study made no evaluation analysis on humans, and all collected data were publicly available.

Informed Consent Statement: Informed consent was obtained from all subjects involved in the study.

Data Availability Statement: All data is stored at the Polytechnic University of Turin, and is available from the corresponding author on reasonable request.

Conflicts of Interest: The authors declare no conflict of interest.

\section{References}

1. Acabado, S.; Martin, M. Between pragmatism and cultural context. Continuity and change in Ifugao wet-rice agriculture. In Water $\mathcal{E}$ Heritage. Material, Conceptual and Spiritual Connections; Willems, W.J.H., van Schaik, H.P.J., Eds.; Sidestone Press: Leiden, The Netherlands, 2015; pp. 273-296.

2. Gao, J.; Lin, H.; Zhang, X. Locally situated rights and the 'doing' of responsibility for heritage conservation and tourism development at the cultural landscape of Honghe Hani Rice Terraces, China. J. Sustain. Tour. 2021, 29, 193-213. [CrossRef]

3. Walter, R.K.; Hamilton, R.J. A cultural landscape approach to community-based conservation in Solomon Islands. Ecol. Soc. 2014, 19, 41. [CrossRef]

4. Gu, H.; Jiao, Y.; Liang, L. Strengthening the socio-ecological resilience of forest-dependent communities: The case of the Hani Rice Terraces in Yunnan, China. Forest Policy Econ. 2012, 22, 53-59. [CrossRef]

5. Yehong, S.; Qingwen, M.; Junchao, S.; Yabing, J. Terraced Landscapes as a Cultural and Natural Heritage Resource. Tour. Geogr. 2011, 13, 328-331. [CrossRef]

6. Acabado, S.; Martin, M. Decolonizing the past, empowering the future: Community-led heritage conservation in Ifugao, Philippines. J. Community Archaeol. Heritage 2020, 7, 171-186. [CrossRef]

7. Cianciulli, A.; Realacci, E. Soft Economy; Rizzoli: Milano, Italy, 2005.

8. Caffyn, A. "Slow Tourism". In Special Interest Tourism: Concepts, Contexts and Cases; Agarwal, S., Busby, G., Huang, R., Eds.; CAB International: Wallingford, UK, 2017; pp. 183-195.

9. Santoro, A.; Venturi, M.; Agnoletti, M. Agricultural Heritage Systems and Landscape Perception among Tourists. The Case of Lamole (Chianti) Italy. Sustainability 2020, 12, 3509. [CrossRef]

10. Corrado, F.; Dematteis, G. Mountains communities between isolation and contamination. In Mountain Landscapes. A decision Support System for the Accessibility; Sargolini, M., Gambino, R., Eds.; List: Trento, Italy, 2013; pp. 148-152.

11. Remotti, F. Cultura. Dalla Complessità All'impoverimento; Laterza: Roma-Bari, Italy, 2011.

12. Bertolino, M.A.; Corrado, F. Cultura Alpina Contemporanea E Sviluppo Del Territorio; FrancoAngeli: Milano, Italy, 2017.

13. De Lalouvière, N. Conceptualising 'Cultural Landscape Commons': Retracing Ecological Thinking from the Swiss Alpine Landscape to Social-Ecological Systems. Revue Géographie Alp. 2021, 1, 1-13. [CrossRef] 
14. De Madariaga, C.J. Dry stone constructions-Intangible cultural heritage and sustainable environment. J. Cult. Heritage Manag. Sustain. Dev. 2021, 11, 614-626. [CrossRef]

15. Magnaghi, A. Dalla Partecipazione All'autogoverno Della Comunità Locale: Verso Il Federalismo Municipale Solidale. Democrazia e Diritto; FrancoAngeli: Milano, Italy, 2006.

16. ISMEA. Il Paesaggio Rurale Storico e Tradizionale: Individuazione Degli Elementi Storici e Delle Fonti. 2016. Available online: Www.reterurale.it (accessed on 25 July 2021).

17. Di Fazio, S.; Modica, G. Historic Rural Landscapes: Sustainable Planning Strategies and Action Criteria. The Italian Experience in the Global and European Context. Sustainability 2018, 10, 3834. [CrossRef]

18. Fontanari, E.; Patassini, D. Planning, Policies and Governance for Terraced Landscape: A General View. In World Terraced Landscapes: History, Environment, Quality of Life; Varotto, M., Bonardi, L., Tarolli, P., Eds.; Environmental History 9; Springer Nature: Cham, Switzerland, 2019; pp. 323-333.

19. Marson, A. Integrated Policies for Terraces: The Role of Landscape Observatories. In World Terraced Landscapes: History, Environment, Quality of Life; Varotto, M., Bonardi, L., Tarolli, P., Eds.; Environmental History 9; Springer Nature: Cham, Switzerland, 2019; pp. 335-347.

20. Bagnod, G.; Chenal, G.; Corsi, A.; Letey, M.; Mazzarino, S. The "Pergola Valdostana" and Heroic Viticulture in Aosta Valley (Italy): A Case Study on a Traditional Wine-Growing System. Ann. Ser. Hist. Sociol. 2020, 30, 99-112.

21. Barsimi, M. Architettura Topiaria, in Carema Terra di Vino e di Emozioni; Barsimi, M., Ed.; Hever: Ivrea, Italy, 2013.

22. Finger-Stich, A. Innovation in the plural of the alpine cre-actors. Rev. Géographie Alp. J. Alp. Res. 2009, 1, 76-82. [CrossRef]

23. Corrado, F.; De Rossi, A.; Durbiano, E. Piano Strategico “Dalla Dora al Mombarone. Available online: https://comune. settimovittone.to.it/images/pianostrategicodalladoraalmombarone.pdf (accessed on 22 July 2021).

24. Hall, C.M.; Sharples, L.L.; Cambourne, B.; Macionis, N. (Eds.) Wine and Tourism from Around the World; Buterworth Heinemann: Londra, UK, 2000.

25. Bushe, G.R. The appreciative inquiry model. In Encyclopedia of Management Theory; Kessler, E.H., Ed.; Sage Publications: New York, NY, USA, 2013; Volume 1, pp. 41-44.

26. Acocella, I. L'uso dei focus groups nella ricerca sociale: Vantaggi e svantaggi. Quad. Sociol. 2005, 37, 63-81. [CrossRef]

27. Omizzolo, A.; Maino, F.; Bona, A.; De Bacco, M.; Fanoni, G. La viticoltura di montagna come leva per la rivitalizzazione socioeconomica delle aree montane marginali. Il caso del vigneto sperimentale di Seren del Grappa. In Proceedings of the Fifth International Congress on Mountain and Steep Slope Viticulture "Extreme viticulture: Values, Beauties, Alliances, Vulnerabilites", Susegana, Italy, 29 March-1 April 2017.

28. Zottele, F.; Santana, A.G. "Faraway, So Close!": The Landscapital Proof-of-Concept Applied of the Terraced Landscapes of the Canary Islands (Spain) and of Val di Cembra (Italian Alps). Vegueta. Anu. Fac. Geogr. Hist. 2021, 21, 319-342. [CrossRef]

29. Ami Osservatorio Paesaggio. Scheda di Precandidatura dei Paesaggi Terrazzati Viticoli Alle Falde Del Mombarone Nell'ambito dell'Anfiteatro Morenico di Ivrea nel Registro Nazionale dei Paesaggi Rurali Storici e Delle Pratiche Agricole E Conoscenze Tradizionali. Available online: http://www.amiosservatoriopaesaggio.it/pluginAppObj_52_21/Scheda-precandidaturadefinitiva.pdf (accessed on 22 July 2021).

30. Corrado, F.; Durbiano, E. Innovative Practices and Strategic Planning on Terraced Landscapes with a View to Building New Alpine Communities. In World Terraced Landscapes: History, Environment, Quality of Life; Varotto, M., Ed.; Environmental History 9; Springer Nature: Cham, Switzerland, 2019; pp. 311-321.

31. Varotto, M. Piccola Terra; Cierre Edizioni: Verona, Italy, 2012.

32. Scaramellini, E.; Varotto, M. Terraced landscape of the Alps. Atlas. ALPTER Project; Marsilio: Venezia, Italy, 2008.

33. Festa, G.; Shams, S.M.R.; Metallo, G.; Cuomo, M.T. Opportunities and challenges in the contribution of wine routes to wine tourism in Italy-A stakeholders' perspective of development. Tour. Manag. Perspect. 2020, 33, 100585. [CrossRef]

34. Wang, Z.; Marafa, L. Tourism Imaginary and Landscape at Heritage Site: A Case in Honghe Hani Rice Terraces, China. Land 2021, 10, 439. [CrossRef]

35. UNESCO [United Nations Educational, Scientific and Cultural Organisation]. Community Development Through World Heritage. World Heritage Papers 31; UNESCO: Paris, France, 2012; Available online: http://whc.unesco.org/en/series/31/ (accessed on 25 July 2021).

36. Bevan, A.; Conolly, G. Mediterranean Islands, Fragile Communities and Persistent Landscape; Cambridge University Press: Cambridge, UK, 2013.

37. Varotto, M.; Bonardi, L.; Tarolli, P. (Eds.) World Terraced Landscapes: History, Environment, Quality of Life; Springer: Cham, Switzerland, 2019.

38. Acovitsioti-Hameau, A. Terraced Lands: From Put in Place to Put in Memory. In World Terraced Landscapes: History, Environment, Quality of Life; Varotto, M., Bonardi, L., Tarolli, P., Eds.; Springer: Cham, Switzerland, 2019.

39. Haubenhofer, D.K.; Blom-Zandstra, M.; Kattenbroek, I.; Brandenburg, W.A. Green Care as an opportunity for knowledge system, learning and collective action across Europe. In Proceedings of the 9th European IFSA Symposium; Wien Universitat fur Bodenkultur, Wien, Austria, 4-7 July 2019. 